\title{
Viramente: Relato de uma Experiência Antimanicomial
}

\author{
Tarpani, Bruno; Ramos, Bárbara Grazielli; Luiz, Marcelo Figueiredo Rodini; Hasse, \\ Mariana \\ FFCLRP-USP — brunotarpani@hotmail.com
}

INTRODUÇÃO o coletivo Viramente possui como ideal o questionamento do lugar ocupado pela loucura na sociedade. Surgiu da agregação de movimentos comprometidos com a luta pela cidadania e acesso à cultura como meio de transformar e agenciar encontros. OBJETIVOS Dentro deste modelo de intervenção que tem caracterizado ações dos coletivos municipais, o Viramente nasce com o objetivo de promover a integração de usuários de serviços de saúde mental com a comunidade e o debate sobre o fenômeno da loucura através da suspensão de papéis comuns. Questionamentos sobre a patologização de comportamentos, tratamento oferecido pelos serviços públicos de saúde e as relações que os perpassam, e o lugar reservado à loucura no imaginário e cotidiano são alguns aspectos que interessam ao coletivo instigar à reflexão e transformação. METODOLOGIA Escolhemos o Dia da Luta Antimanicomial (18/04/2013) para experimentarmos nossas ideias. na época, ocorriam na cidade do evento os preparativos para a Segunda Virada Cultural Independente, encabeçada por um coletivo de movimentos sociais local. As discussões sobre uma ação para o Dia da Luta Antimanicomial surgiram no mesmo período e foram incorporadas aos eventos da Virada Independente. o resultado foi a reunião entre profissionais, usuários de serviços, estudantes e movimentos sociais para pensar uma nova forma de trazer à sociedade a importância de debater a loucura e suas relações com a vida social. Foram organizadas atividades artísticas e educativas que proporcionassem encontros e reflexões sobre os paradigmas da Reforma Psiquiátrica e das representações sociais do sofrimento mental. RESULTADO o lugar escolhido para uma aproximação com a comunidade foi um parque municipal de fácil acesso ao público, no qual ocorreram diversas oficinas, apresentações culturais, rodas de conversa e exposições culturais. As atividades oferecidas tiveram grande participação e visibilidade e o efeito almejado pelo coletivo era a interação dos participantes de igual para igual, sem saber quem era usuário, médico, enfermeiro, estudante ou artista. Eram apenas pessoas (con)vivendo. Além das interações em vivências e dinâmicas, a repercussão dos debates realizados mostrou-se instigante quando evidenciou a propriedade que os usuários têm ao falar sobre seu próprio sofrimento, gerando reflexões sobre as verdades estabelecidas sobre a loucura, seja no conhecimento popular ou científico. CONCLUSÕES a construção de um momento em que discursos de conscientização deem espaço a experiências e encontros, no qual a comunidade possa expor suas angústias e opiniões sobre os temas aqui tratados foi real nesse dia. Nosso coletivo deseja continuar no caminho dessas experimentações, permitindo que a surpresa dessas vivências se efetue e retorne para a realidade na forma de novas atitudes, que possam ser (re)construídas cotidianamente e assim, transformar efetivamente as relações humanas.

Tarpani, Bruno; Ramos, Bárbara Grazielli; Luiz, Marcelo Figueiredo Rodini; Hasse, Mariana. Viramente: Relato de uma Experiência Antimanicomial. In: Anais do Congresso Internacional de Humanidades \& Humanização em Saúde [= Blucher Medical Proceedings, num.2, vol.1]. São Paulo: Editora Blucher, 2014. ISSN 2357-7282 DOI 10.5151/medpro-cihhs-10527 